\title{
PÓKA RÓBERT
}

\section{FELTÁRATLAN EMLÉKEK KENÉZY GYULA ÉLETÉBÖL ÉS MUNKÁSSÁGÁBÓL}

\begin{abstract}
UNEXPLORED MEMORIES FROM THE LIFE AND WORK OF GYULA KENÉZY. Gyula Kenézy is an outstanding historical figure of the University of Debrecen as well as of the City of Debrecen. Beyond many sculptures, street, prize, a hospital, and a civil society which carry his memories, the cities of Debrecen and Hajduiszoboszló regularly remember the renowned professor. Many monographs gave the account of his life and accomplishments, and a collection of his relics gained a permanent place for commemoration in the Museum of Hajduiszoboszló. Nevertheless, one-hundred years after the beginning of medical education in Debrecen, new pieces of historical records continue to enrich our memories about Gyula Kenézy. For the first time in its history, the Kenézy Memorial Day was organized by the Kenézy Civil Society and the University of Debrecen together in 2017. The program provided us with exciting recollections, and so far unraveled details of the life of Gyula Kenézy.
\end{abstract}

\section{Bevezető}

2017 októberében a Debreceni Egyetem Kancellária Rendezvénykoordinációs és Alumni Központjának vezetője levélben tájékoztatott arról, hogy ebben az évben a Kenézy Gyula Emléknapot a Debreceni Egyetem szervezésében a Kenézy Villában tartjuk 2017. november 28-án, kedden 10 órai kezdettel. A központvezető az egyetem vezetése nevében kért fel engem, úgy is, mint a Kenézy Gyula Baráti Kör tagját, hogy tartsak előadást az Emléknap keretében.

A Szülészeti és Nőgyógyászati Klinika igazgatójaként a kilencedik utód számára kijelölt feladatot természetesen kötelességnek és megtiszteltetésnek éreztem legjobb tudásom szerint teljesíteni. Válaszomban a „Kenézy Gyula emléke és hagyatéka a XXI. században” vagy a "Kenézy Gyula a kilencedik utód szemével” címeket javasoltam előadásom tárgyául. Végül, az utóbbira esett a választás.

Annak ellenére, hogy már 2013-as klinikaigazgatói kinevezésem idején is az elődök emlékének ápolását tekintettem az egyik legfontosabb célkitűzésemnek, és ennek megfelelően azóta is minden évben ünnepélyes keretek között emlékeztünk meg egyegy elődünkről (Kenézy Gyula szoboravatása 2013-ban, Lampé László és Borsos Antal professzorok 85., illetve 75. születésnapja 2014-ben; Takács István professzor halálának 30. évfordulója 2015-ben; Árvay Sándor szoboravatása 2017-ben; Papp Zoltán professzor 75. születésnapja 2017-ben), mégis a Kenézy Gyuláról való megemlékezést igazgatói pályafutásom egyik legnehezebb kihívásának tekinthettem. 
A feladat nehézségét mindenekelőtt az jelentette, hogy Kenézy Gyuláról, életéről és munkásságáról számos kiadvány jelent már meg. Emlékét elődeim, a város vezetése, a Kenézy Kórház, a Magyar Honvédség 5. számú Bocskai István Lövészdandárja és a Dr. Kenézy Gyula Baráti Kör Civil Társaság is rendszeresen ápolják. Ugyanakkor egyetemi tanárként arra éreztem késztetést, hogy a méltó megemlékezést - az akadémiai közlésekben megszokott módon - új tényekkel, eddig nem ismert adatokkal tegyem színesebbé, érdekesebbé. Ennek megfelelően, a rendelkezésre álló másfél hónapban „szabadidőm" minden percét Kenézy Gyula életrajzi adatainak kutatásával töltöttem.

Fontosabb életrajzi adatai már ismertek, kortársai

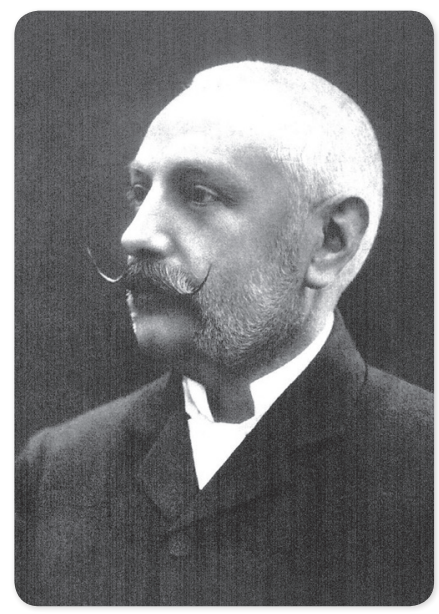
nem élnek már. Lehet így újat mondani róla? Kezdetben elég kilátástalannak tủnt ez a vállalkozás, de néhány nap után olyan áttörést élhettem meg, amelyet egy máig véget nem éro, „megszállott” kutatás kezdetének tekintthetek.

Mindaz, amit Kenézy Gyuláról régóta tudunk, az alábbiakban foglalható össze tételesen:

- 1860. január 4-én Hajdúszoboszlón született;

- Budapesten szerezte meg az orvosi diplomát 1881-ben;

- 1885-ben debreceni tisztiorvos lett;

- 1893-ban kórházi igazgató fóorvossá nevezték ki;

- 1896-ban a debreceni bábaképző intézet, majd a gyermekmenhely igazgatója lett;

- 1908-ban az egyetem első rendkívüli tanára, az Egyetemi Állandó Bizottság elnöke lehetett;

- 1914-ben a Debreceni Tudományegyetem első nyilvános rendes tanárának nevezték ki;

- 1916-ban a a, kezdetben még a Bábaképző Intézet épületében működő Szülészeti Klinika első igazgató professzora lett;

- 1918/19-ben az Orvoskar dékánja volt;

- 1920/21-ben az Orvoskar prodékánja,

- 1920/21 Debreceni Egyetem rektora,

- 1921/22 Debreceni Egyetem prorektora volt;

- 1924-ben az Egyetem díszdoktorává avatták;

- 1930-ban nyugdíjazták;

- 1931. november 25-én halt meg gégerákban.

E tények felsorolása lényegében nem több, mint a kitüntetések díszpárnán való elhelyezése egy temetésen. Szándékom szerint Kenézy Gyula személyiségéről szerettem volna többet megtudni, és átadni az emléknap résztvevőinek. 
Ki volt Kenézy Gyula? Kik voltak a személyiségét meghatározó szülei és tanárai? Kik voltak a barátai? Kik voltak a példaképei? Kortársaival milyen kapcsolatban állt, milyen kapcsolatokat ápolt? Hogyan beszélt? Milyen volt a világnézete? Melyek voltak számára korának legfontosabb kérdései? Hogyan tudta olyan szerteágazóan befolyásolni környezetét?

Az ezen felsorolt kérdésekre keresett válaszok eredményessége arra ösztönzött, hogy előadásom címét „Kenézy Gyula családi és társadalmi kapcsolatai”-ra módosítsam. Vitathatatlan, hogy az elért sikerekben különösen fontos szerepe volt a családi és baráti környezetnek, valamint a példamutató munkatársaknak, tanároknak és a kor meghatározó személyiségeinek.

\section{Családi háttér}

\section{Az édesanya, a feleség és az anyós}

Minden sikeres férfi mögött ott áll egy nő - tartja a mondás, és ez Kenézy Gyula esetében sem volt másképp. Anyja, Debreceni Zsuzsanna, bábaasszony, felesége, gelei Bársony Lujza (római katolikus, Nagykároly, 1862. augusztus 23.-Debrecen, 1928. április 16.), aki Bársony János (római katolikus, Nagykároly, 1860. július 31.-Budapest, 1926. február 28.) budapesti tudományegyetemi szülészprofesszor (1903-1926) és Bársony István (római katolikus, Keresztes, 1855. november 15.-Budapest, 1928. március 11.) író, újságíró testvére volt.

Kenézy Gyula szülészettel kapcsolatos indíttatása kétségtelenül édesanyjához kapcsolódik. A XIX. században megbecsült foglalkozás volt a bábaság, és a gyermeki kíváncsiságnak Kenézy esetében is nyilván valóan kiemelt területe volt édesanyja mindennapi munkája. Mai szemmel szokatlan, hogy könyveiben Kenézy Gyula sohasem hivatkozott az édesanyjától hallottakra, de ezzel együtt már az sem meglepő, hogy az általa olvasott szerzők neveit, tanárai mondásait vagy saját szakmai élményeit sem említi meg. Édesanyjáról, Debreceni Zsuzsannáról fénykép máig nem került elő.

Kenézy Gyula nagy tisztelettel érzett anyósa, Bársony Jánosné Fásy Lujza iránt is. Ezt az is igazolja, hogy Fásy Lujzát 1903-ban nem Budapesten, a szintén szülész professzor ifj. Bársony János városában, hanem Debrecenben temették el, az „új” kórház közelében lévő temetőben. Ez minden bizonnyal Kenézy feleségének, Bársony Lujzának, a Bársony testvérek legfiatalabb tagjának kérése volt.

\section{Bársony János, a munkatárs és sógor, majd szülész professzortárs}

Kenézy Gyula nem csak kortársa, diáktársa és munkatársa volt Bársony Jánosnak (1860. július 31. Nagykároly-1926. február 28. Budapest), a későbbi szülészeti klinikaigazgatónak, hanem a sógora is. A közvetlen családi kapcsolattá alakult baráti és munkatársi 
kapcsolat nyilvánvalóan komoly hatással bírt Kenézy pályafutásának alakulására. Családi és társadalmi kapcsolatai között talán ez tekinthető a legjelentősebbnek.

A barát és sógor szülei Bársony János gazdatiszt és Fásy Lujza voltak. Testvére Bársony István (1855-1928) író. Orvosi tanulmányait Bécsben kezdte, a budapesti tudományegyetemen orvosdoktori oklevelet (1884), majd szülészeti mütéttanból magántanári képesítést szerzett (1891). A Budapesti Tudományegyetem, illetve a Pázmány Péter Tudományegyetem Szülészeti Klinikáján Kézmárszky Tivadar gyakornoka volt, egyetemi tanársegéd (1884-1903), az I. sz. Szülészeti és Nőgyógyászati Klinika magántanára (1891-1903), majd a szülészet és nőgyógyászat nyilvános rendes tanára és Kézmárszky halálát követően a klinika igazgatója (1903-1926) lett. Az egyetem rektora volt 1922/23-

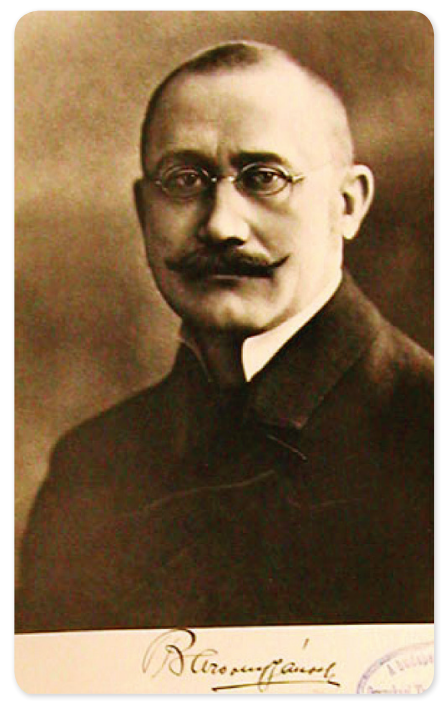
ban; közben a Vöröskereszt Budapesti Erzsébet Kórház főorvosa is (1901-1903) volt. Jelentős eredményeket ért el a méhen kívüli terhesség mütéti megoldásai, a gyermekágyi láz gyógyítása terén. Szélsőséges nacionalista nézeteket vallott, a budapesti egyetemen a numerus clausus egyik bevezetője és támogatója volt. Alapító tagja volt a Magyar Orvosok Nemzeti Egyesületének (MONE).

\section{Dr. Kovács Gábor, Kenézy Lujza férje}

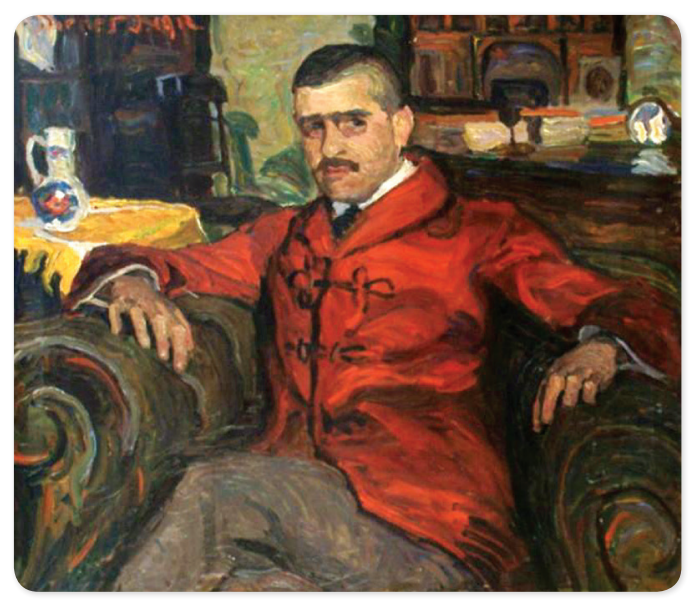

Kenézy lánya, Lujza 1887-ben született. Utóbb férje dr. Kovács Gábor (1883-1920) jogász-közgazdász tudós lett, akit 31 éves korában az akkor alakuló Debreceni Tudományegyetem Jog- és Államtudományi Karán volt nyilvános rendes egyetemi tanár. A róla készült festményt a miskolci Herman Ottó múzeum örzi. A rendkívüli tehetségű jogász, közgazdász tudósnak, valamint szüleinek és családjának emlékét Miskolcon nagy tisztelet övezi.

A kiemelkedő tehetségű fiatalember még a Debreceni Tudományegyetem megalakulása előtt kapott professzori kinevezést a jogelőd Református Kollégium jogi fakultásán, majd az újonnan létre hozott Jog- és Államtudományi Karának tanszékvezető egyetemi tanárává nevezték ki. Hogy 
kapcsolata mennyire szoros volt apósával, mi sem bizonyítja jobban, mint az, hogy Kenézyt jóval korábban megismerte, mint a lányát. Kenézy 1891-ben jelentkezett a debreceni Haladás páholyba, ahova alig egy hónap múlva fel is vették. A páholy aktív tagja, hamarosan fömestere lett. Kovács Gábor évekig a páholy egy-egy vezető tagjánál lakott albérletben. Kenézy 1913-ban több társával együtt kilépett a Haladás páholyból és megalapították a Kőrösi Csoma páholyt. Kenézy $A$ szabadkömüvesség lényege címmel 1910-ben felvilágosító munkát jelentetett meg, de a Körösi Csoma páholy programját nem más, mint Kovács Gábor írta meg.

\section{Az egyetemi évek hatása}

\section{Makara Lajos, a tudományos diákkörös szerzőtárs}

Kenézy Gyula orvostanhallgatóként Makara Lajossal (Pápa, 1862. március 20.-Kolozsvár, 1915. november 5.) volt a legszorosabb kapcsolatban. Diákkörösként együtt végezték tudományos munkájukat a Lenhossék-dinasztia második generációját képviselő Lenhossék József által vezetett és éppen Kenézyék idejében felépített Üllői út 26. alatti anatómiai intézetben. Ez volt az első, korszerű anatómiai intézet az országban. Témavezetőjük Mihálkovics Géza volt. Még Lenhossék József életében 1882-ben a tanszéket I. és II. sz. anatómiai intézetre bontották, és a II. sz. intézetet előbb Mihalkovics Géza vette át, majd Lenhossék József halála után ő átkerült az I. sz. intézetbe. Kenézy Gyula és Makara Lajos negyedéves korukban közösen készített pályamunkája a nyak tájanatómiájáról első díjat nyert. Az orvos és egyetemi tanár Makara Lajos orvosi oklevelét 1885-ben szerezte meg. 1885 és 1887 között az anatómiai intézet munkatársa, 1887-től az I. sz. sebészeti klinikán tanársegéd volt, majd 1898-ban a sebészet magántanára lett. 1905-től haláláig a kolozsvári egyetem I. sz. sebészeti klinikájának az igazgatója, nyilvános rendes tanár volt. Sebészeti anatómiával és preparatív mütéti technikával foglalkozott. Főbb művei „Az emlörák sebészi kezelésének mai állása” (Budapest, 1897); „A végtagok sebészeti bántalmainak gyógyitása” (Budapest, 1905); „Tapasztalatok a lumbális analgesiáról és e tan mai állása” (Budapest,1906); „A Mayo-féle gyökeres köldöksérvmütétröl” (Kolozsvár, 1907); „A nyaki gümős lymphomákról” (Budapest,1913); „Tájékoztató a hadi sebészetröl” (Kolozsvár, 1915) voltak.

\section{A Budapesti Tudományegyetem Orvoskara Kenézy egyetemista és kezdő orvosi éveiben (1880-1885)}

A rossz felszereltség mellett a budapesti orvoskar legföbb gondja a helyszűke volt Kenézy idejében. 1848-ban ugyan elvitték végre a klinikákat az Újvilág utcai épületből, de ez csak átmenetinek bizonyult, mivel a forradalom leverése után visszaköltöztek oda. 
A Szent Rókus Kórház továbbra is elzárkózott a klinikák befogadása elől, a föváros pedig hosszú ideig nem biztosított telket az építkezések számára. Átmeneti enyhülést jelentett a Kunewalder-féle terményház (az akkori Országúton, a mai Múzeum körúton) megszerzése 1858-ban, amit eredetileg az Állatorvosi Intézet számára vásároltak. Ide költözhetett át a sebészet (Balassa), az állattan, az élettan és az ekkor Semmelweis vezette szülészet, valamint a teljes kari adminisztráció. Igazi megoldást azonban csak az 1873 és 1911 között megvalósult, és mintegy 25 millió koronát fölemésztő nagyszabású építkezések hoztak, melyek egészen 1911-ig tartottak. Ekkor vált az akkor még igencsak külterületnek számító Üllői út az Orvoskar tengelyévé, ahol két telepen helyezték el a klinikákat, a füvészkertet és az adminisztrációt. Ezzel egy időben, gyors egymásutánban alakultak az új, gyakran párhuzamos, de kivétel nélkül a kor színvonalán álló, kielégítően felszerelt tanszékek. Az 1880-as évekre számuk mintegy megnégyszereződött. E máig egyedülálló fejlesztésekben kulcsszerepet játszottak a Vallás- és Közoktatásügyi Minisztérium részéről Eötvös József és Trefort Ágoston miniszterek, valamint Berzeviczy Albert államtitkár, Markusovszky Lajos tanácsos, az Orvoskaron pedig Balassa János (bár ez vitatható - lásd később), Korányi Frigyes és Tóth Lajos, későbbi államtitkár.

\section{Balassa János (1814-1868)}

A „virtuóz” sebészprofesszor közvetlenül azért nem játszhatott szerepet a századvégi budapesti orvoskari fejlesztésekben, mert 1868-ban vakbélgyulladásban meghalt. Értelemszerüen, Kenézynek sem volt tanára, így debreceni egyetemalapítónk személyiségére csak közvetett hatással bírhatott. Balassa János Kossuth és Deák bizalmasa volt, $s$ amikor kimondták a tanszabadságot, Eötvös József kinevezte a pesti egyetem orvosi ügyeinek igazgatójává. 1948/49-ben az orvosi kar igazgatója volt. A szabadságharc idején a klinikát honvédkórházzá alakította át. A szabadságharc bukása számára is hivatalvesztést és börtönt jelentett. Batthyány Lajossal cellaszomszédok voltak. A monarchiához hủ kortársai nyomására az ifjú Ferenc József kegyelmet adott neki. A Bach-korszak dékánja meneszteni akarta, de a diákok követelésére 1851-ben újra klinikaigazgató lett. A legnagyobb kitüntetés számba ment, amikor Erzsébet királyné őt választotta magyar orvosául. Balassa János a királyné szülészorvosa volt a budai várban, amikor 1868. április 22-én Valéria főhercegnő született. Ez alkalommal a királyné - nevének kezdőbetűjével díszített - gyémántgyűrußt ajándékozott kedves magyar orvosának. Szakmai szempontból fontos megemlíteni, hogy Balassa volt az első orvos Magyarországon, aki éteres altatást alkalmazott műtéti beavatkozásaihoz. 
(tolcsvai) Korányi Frigyes (1828-1913)

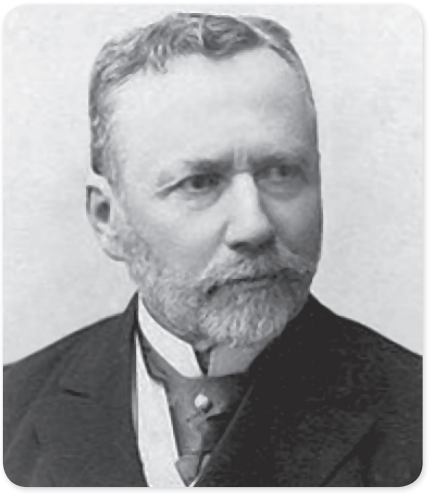

A híres és népes nagykállói Kornfeld család sarja volt Korányi Frigyes. Orvostanhallgatóként rész vett az 1848/49-es forradalom és szabadságharcban. Pesten, 1852-ben szerzett diplomát. 1857-1858 között több tanulmányutat tett a kor legnevesebb orvosi intézményeibe, illetve egyetemeire Markusovszky Lajossal, Hirschler Ignáccal és Török József „debreceni gyógyszerésszel" együtt (Ez utóbbi tévedést később tisztázzuk). A magyar alkotmány felfüggesztése (provizórium) elleni tiltakozásul 1861. november 4-én a teljes megyei tiszti karral együtt lemondott. (A provizórium egészen a kiegyezésig tartott). 1864-ben amnesztiát kapott és visszatérhetett Pestre, ahol előbb a tífusz-fiókkórház, majd 1865-ben a pesti Szent Rókus-kórház idegosztályának vezetője lett. 1864-ben a pesti egyetemen magántanári képesítést szerzett idegkórtanból. 1866-ban kinevezték a pesti egyetemen a belgyógyászat tanárává. Részt vett az 1870-es évek egészségügyi reformjainak előkészítésében és kidolgozásában (1874. évi egyetemi orvosképzési reform, 1876. évi közegészségügyi törvény), s ennek révén számos korábbi, még tanulmányútjai során megfogalmazódott reformelképzelését keresztül tudta vinni. Munkássága elismeréseként 1884-ben „tolcsvai” előnévvel (Adolf nevü öccsével együtt) nemesi, majd (egymaga) 1908-ban bárói rangot kapott, 1891-ben a fórendiház örökös tagja lett. 1886-ban kinevezték egyetemi rektorrá. Kenézy életének alakulását közvetve, de jelentősen befolyásolta az orvosképzési reform és a közegészségügyi törvény. A belgyógyászat tanáraként Korányi Frigyes közvetlenül is hatással volt Kenézy Gyula személyiségének fejlődésére.

\section{Török József, debreceni gyógyszerész?}

Ki is volt az a debreceni gyógyszerész, akivel Korányi, Hirschler és Markusovszky bejárta Európa legnevesebb egyetemi klinikáit? A válaszadáshoz induljunk el a hazai gyógyszerészet történeti emlékeiből.

1839-ben Wagner Dániel gyógyszerész, az első magyar vegyészdoktor a Magyar Tudós Társasághoz benyújtott és pályadíjjal jutalmazott dolgozatában vegyészeti gyár alapítását javasolta. 1847-ben, elsősorban a Wagner-család részvételével 25000 pengőforint alaptőkével meg is indult a vállalkozás. 1867-ben tartotta alakuló közgyülését a Központi Magyar Gyógyszerészeti és Művegyészeti Vállalat Részvénytársaság, amely a Wagner-féle Soroksári úti gyárat vette át. Igazgatóságában szerepeltek dr. Wagner Dániel, dr. Balassa János és dr. Korányi Frigyes orvos professzorok, dr. Vass Illés és 
Vlasek Ede gyógyszerészek. A Labor Gyógyszer- és Vegyészeti Gyár 1884-ben, a Galenus Gyár, mely a szacharint gyártotta, 1904-ben alakult meg.

A tudományos kutatásokon alapuló gyógyszeripari kezdetét Richter Gedeon munkássága jelenti. Richter Gedeon sikere azon alapult, hogy Európában a legelsők között ismerte fel az organoterápia jelentőségét. Vállalkozása néhány év alatt kinőtte a kisüzemi termelés kereteit, a kis gyógyszerészeti laboratóriumot. Gyáralapítási tervéhez ugyan nem kapott támogatást, de a kőbányai gyár 1907-ben államsegély nélkül is felépült. 1909-ben az államsegélyt is megkapta, és 1923-ban részvénytársasággá alakult.

A Labor Gyógyszer- és Vegyészeti Gyár Rt. utóbb, 1932-ben egyesült a Török József Rt.-vel Török-Labor Gyógyáruanyag-kereskedés és Vegyészeti Gyár Rt. néven. A névadó Török József 1848-ban Párizsban folytatott gyógyszerészi tanulmányokat. Kapcsolatba került a párizsi magyar emigrációval, anyagilag is támogatta őket. Török József 1861-ben hazatért, és megvásárolta az 1813-ban alapított Szent Lélek (v. Gömöri) patikát. Egyik megalapozója volt a hazai gyógyszer-nagykereskedelemnek. 1861-től pesti városi politikusként, különböző alapítványok támogatójaként, a Honvéd-egyletek mecénásaként volt ismert.

Úgy tűnik, hogy ez a Török József azonban nem az, aki Kenézy Gyulával bármilyen kapcsolatban állhatott.

Felmerül ugyanakkor az a lehetőség, hogy az egyedülálló budapesti egyetemi fejlesztésekben, az „Üllői úti tengely” létrehozásában egy debreceni gyógyszerész Török József játszott szerepet. Kutakodván a hazai gyógyszerészet debreceni történelmi emlékei között, megtudhatjuk, hogy a Debreceni Gyógyszervegyészeti Gyárat Rex Ferenc alapította 1908-ban - ebből nőtt ki a Rex Gyógyszervegyészeti Gyár. Ismert volt a Strauss Jenő és Strauss Imre Gyógyszerészeti Gyár is (1909). A korabeli hirdetések (Diana arc-szesz, Hölgy-óvszer) böngészése alapján ugyanakkor az is feltételezhető, hogy nem az említett, híres budapesti patikus Török József volt az, aki Markusovszky és Korányi oldalán a budapesti egyetemi beruházásokat akadémiai, kormányzati és politikai eszközökkel befolyásolni lett volna képes, mivel kitartó kereséssel rábukkanhatunk egy debreceni Török Józsefre is.

\section{Török József, debreceni orvostudós}

Török József orvos, egyetemi tanár, az MTA tagja (levelező 1843, rendes 1858) Alsóváradon született 1813. október 14-én és Debrecen halt meg 1894. március 14-én. Török Pál református püspök öccse volt. 1842-ben szerezte meg orvosi oklevelét a pesti orvosi karon, 1843-ban sebész- és szülészmester lett. 1842/43-ban Berlinben, Párizsban és Bécsben képezte tovább magát. 1843-1845 között Debrecenben gyakorló orvos, 1845-1848-ban a Természettudományi Társulat másodtitkára volt Pesten. 1848-ban a debreceni református főiskolán a természet- és vegytan tanára lett. 1848 


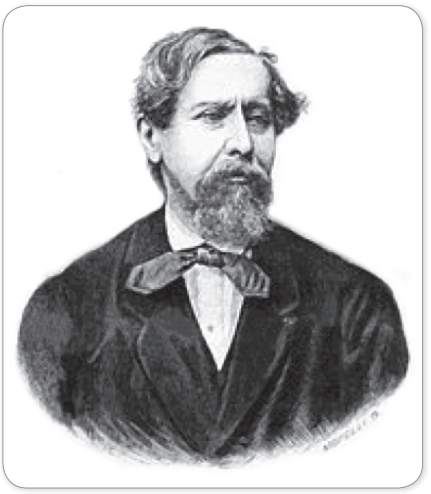

decembere és 1849 áprilisa között a debreceni tábori kórházak föorvosa volt. 1848 májusa és júliusa között a Belügyminisztériumban tanácsos és az egészségügyi osztály munkatársa volt. 1849 őszén visszatért tanári állásába. 1861-1874 között a debreceni jogakadémián a törvényszéki orvostan és közegészségtan nyilvános rendes tanáraként tevékenykedett.

Kenézy Gyulára tekintettel fontos kiemelni, hogy Debrecenben Török ő végezte az első feljegyzett császármetszést. Főbb művel között említhetjük „Magyarország közgazdaságilag nevezetes termékeiröl” (Buda, 1844), „A két magyar haza elsörangú gyógyvizei és fürdőintézetei” (Pest, 1848), „A természettudományok elhanyagolásának káros következményeiröl hazánkra nézve" (Debrecen, 1848) és "Népszerü ember-élettan” (Debrecen, 1881) címü könyveit. Utóbbi kötete Kenézy Gyula tanulmányainak fontos forrása lehetett, hiszen akkoriban még nem müködött orvosi élettani tanszék az országban.

\section{Társadalmi kapcsolatok}

\section{Tóth Lajos}

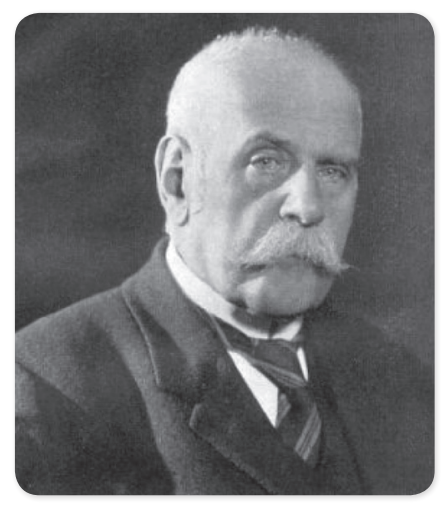

Tóth Lajos (Kiskőrös, 1856. június 11.-Budapest, 1926. december. 14.) nevét az 1880-as években megnégyszereződő budapesti orvoskari tanszékek és az Üllői úti fejlesztések kapcsán már említettük. Nyilvánvaló, hogy Kenézy Gyula hallgató korában és végzést követő budapesti évei során mindennap szemtanúja volt a grandiózus fejlesztéseknek, az építkezéseknek és az orvoskar soha nem látott terjeszkedésének.

Tóth Lajos orvosi oklevelét 1879-ben nyerte a budapesti egyetemen, így hallgatóként Kenézy Gyula diáktársa volt. 1881-től a gyógyszertani tanszék tanársegédjeként dolgozott. 1886-ban gyógyszertanból egyetemi magántanári képesítést nyert. 1890-ben kinevezték a kolozsvári egyetemre a gyógyszertan tanárává, tanszékét azonban nem foglalta el, mert a vallás- és közoktatásügyi minisztériumba rendelték be. Az Országos Közegészségügyi Tanács tagja és jegyzője, a Magyar Orvosok és Természetvizsgálók Központi Bizottságának elnöke volt - bizonyos értelemben a debreceni Török József utóda -, de részt vett az Igazságügyi Orvosi Tanács munkálataiban is. A Markusovszky Lajos által életre hívott haladó orvosi reformgondolat követője volt. Tevékenyen részt vett a budapesti egyetem orvoskarának modernizálásában, valamint 
a pécsi, debreceni és szegedi egyetemek orvoskarának megteremtésében. 1892-1926 között a Vallás- és Közoktatásügyi Minisztérium államtitkára volt. Beosztásánál fogva az egyik legfontosabb szerepet töltötte be a Debreceni Tudományegyetem létrehozásáért folytatott küzdelemben. Egykori diáktársként és munkatársként az Egyetem alapításával kapcsolatos későbbi debreceni és budapesti hivatalos tárgyalások kapcsán minden bizonnyal nosztalgikus beszélgetések zajlottak Tóth Lajos és Kenézy Gyula között.

\section{bókai Bókay Árpád}

Bókay Árpád (Pest, 1856. augusztus 15.-Budapest, 1919. október 20.) orvosi diplomáját 1879-ben kapta meg. Pályáját egyetemi tanársegédként kezdte az egyetem gyógyszertani intézetében. Belgyógyász és farmakológus, a belgyógyászati vizsgálati módszerek magántanára (1881-1883), a kolozsvári egyetemen az általános kór-, gyógytan és gyógyszertan professzora (1883-1890), 1890-től a budapesti egyetemen a gyógyszertan tanára, 1900-1902 között a kar dékánja volt.

Kenézy Gyula élete és személyiségformálása kapcsán fontos említést tennünk Bókay szabadkőműves tevékenységéről, hiszen egyetem alapítónk számára ez

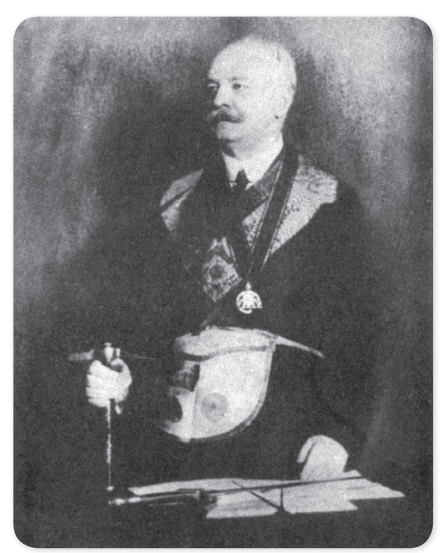
meghatározó példát jelentett. Amikor Bókay Árpád 1902-ben a pesti Pátria páholyba jelentkezett, Hevesi József író így ajánlotta felvételre: „Dr. Bókay Árpád felvételét a testvéri láncba nemcsak tudása, nemcsak fényes állása miatt tartom nagy nyereségnek, de lelkének szárnyalása és szivének nemessége miatt is.” Testvére, Bókay János és fia, Bókay Zoltán is ennek a páholynak voltak a tagjai. A Pátria páholy küldötteként Bókay Árpád bekerült a Magyarországi Szimbolikus Nagypáholy Szövetségtanácsába. 1905-ben helyettes nagymesterré, 1915-ben pedig a magyar szabadkőművesség nagymesterévé választották, amely tisztséget haláláig, 1919-ig betöltötte.

Az I. világháború során 1915. első hónapjaiban az oroszok betörtek Kárpátaljára és leromboltak több falut. Az állam feladatként tűzte ki, hogy az elpusztult falvakat újjáépítsék. A szabadkőművesek az egyik falu, Mezőlaborc rendbehozatalát vállalták és végezték el. Bókay Árpád nagymester a szabadkőműves Világ című újság hirdetéseivel szervezte a gyüjtést, rendszeresen meglátogatta az újjáépülő falut, amelyet ezután Kőművesfalvának neveztek el.

A világháború sebesültjei olyan sokan voltak, hogy kórházak már nem tudták ellátni őket. Ezért a Nagypáholyházat más páholyokhoz hasonlóan - dr. Bókay Árpád irányításával - hadikórházzá alakították át. Az 1918. október 25-én hatalomra jutott Magyar Nemzeti Tanácsot és a Károlyi kormányt a szabadkőművesek saját eszméik megvalósítójának tekintették. Kenézy Gyula munkássága sok hasonlóságot mutat 
Bókay Árpádéval. Szabadkőműves tevékenysége során Kenézy lényegében ugyanazokat a célokat valósította meg Debrecenben, mint Bókay Budapesten.

\section{bókai Bókay Zoltán}

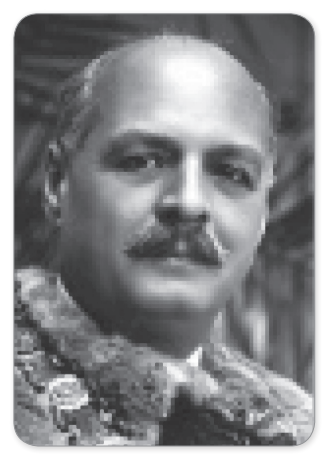

Bókay Árpád fia (Budapest, 1885. szeptember. 9.-Budapest, 1955. április. 1.) abban az évben született, amikor Kenézy viszszatért Debrecenbe. Orvosi oklevelét a budapesti egyetemen szerezte 1908-ban, 1907-től a kórbonctani intézetben gyakornok, majd tanársegéd volt. 1909-től a Stefánia gyermekkórházban működött. Tudva levő, hogy a Stefánia gyermekkórházat a szabadkőművesek tartották fenn. 1916-ban magántanárrá képesítették. 1918-ban került az egyetemi gyermekklinikára. 1926-ban egyetemi címzetes rendkívüli tanár, 1930-tó1 1947-ig a debreceni egyetemen nyilvános rendes tanár, a gyermekklinika vezetője lett. 1951-től haláláig Budapesten a IX. kerületi Poliklinikán, mint föorvos teljesített szolgálatot. A meningitis tuberculosa liquor diagnosztikájával foglalkozott. Több magyar és idegen nyelven megjelent dolgozata foglalkozik az agyhártyagyulladások megkülönböztető kórisméjével. Főbb művei közé sorolhatók az alábbi munkák: „A gyermekorvoslás tankönyve” (Bókay Jánossal és Flesch Árminnal, Budapest, 1912) és „A veleszületett szivbajok monographiája esetek kapcsán" (Budapest, 1913).

\section{Hőgyes Endre és tevékenységének közvetlen és közvetett hatása}

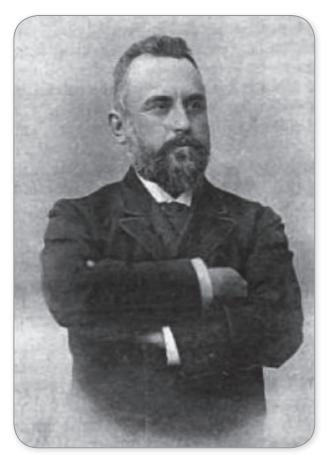

Kétségtelen, hogy Kenézy Gyula személyiségének fejlődésében meghatározó szereppel bírt Hőgyes Endre személye és munkássága. Hőgyes Endre is Hajdúszoboszlón született és nevelkedett, $s$ a város mai is leghíresebb szülöttjeként tartja őt számon.

Hőgyes Endre (Hajdúszoboszló, 1847. november 30.-Budapest, 1906. szeptember 8.) Kenézy Gyula medikus éveiben már a kór- és gyógytan nyilvános rendes tanára volt a budapesti egyetemen. Mivel személyét a hazai orvostörténet leginkább a zoonózisok megelőzése és gyógyítása kapcsán kifejtett tevékenységével azonosítja, kevesen tudják róla, hogy audiológiai kutatásai és az általa kifejlesztett hallásküszöb mérésére alkalmas készülék évtizedekkel előzte meg az 1961-ben orvosi Nobel-díjjal kitüntetett Békésy György munkásságát.

Hőgyes Endre példa értékű egyetemi és akadémiai pályafutásán túl Kenézy Gyula életére legnagyobb hatással a közegészségügy terén folytatott tevékenysége volt. A dua- 
lizmus első évtizedeiben a debreceni Török Józseffel együtt tagja volt a közegészségügyi tanácsnak. Mindketten fontos szerepet játszottak az 1876. évi, a közegészségügy rendezéséről szóló XIV. törvénycikk létrehozásában.

Ez volt az első magyarországi kormányzati intézkedés a közegészségügy szabályozásáról és az első törvény, amely államigazgatási feladatként deklarálta a közegészségügyet. A törvény megalkotásáig semmilyen szabályozás nem létezett az akkoriban nem ritka járványok (pl. kolerajárvány 1872-ben) és katasztrófahelyzetek (pl. árvíz Szegeden 1879-ben) kezelésére, de még az egészségügy (orvosi, körorvosi, szülésznői jogosítvány, kórházak müködési engedélye) és a közegészségügy (gyermekegészségügy, védőoltások, gyógyszerügy) helyhatósági feladatai és jogkörei, valamint a legalapvetőbb - születéssel, halottkémléssel és temetkezéssel kapcsolatos - eljárásrendjei sem voltak rögzítve. Az első közegészségügyi törvény eredményeként jött létre Magyarországon a tisztiorvosi hálózat.

Debrecen törvényhatósági jogú városban az önkormányzat legfelsőbb fóruma a törvényhatósági bizottság volt, amely 1872. július 22-én alakult meg. Miskolczy Lajos elnök-föispán Debrecen szabad királyi város közigazgatási bizottságának megalakulását 1876. október 2-án az alakuló ülésen jelentette be. A bizottság tagjai voltak a főispánon kívül a város polgármestere, fójegyzője, tiszti ügyésze, főorvosa, az árvaszék elnöke, valamint az állami szakhatóságok vezetői, így a királyi adófelügyelő, a királyi államépítészeti hivatal első mérnöke, a királyi közigazgatási tanfelügyelő, a királyi ügyész, a helyi postahivatal főnöke és a törvényhatósági közgyűlés tíz választott tagja.

Kenézy Gyula életrajzának mérföldkövei között olvashatjuk, hogy 1885-ben Debrecen tisztiorvosa lett. Tudjuk, hogy 1885-ig a budapesti Tudományegyetem Szülészeti és Nőgyógyászati Klinikáján dolgozott, így talán egy kissé meglepő, hogy debreceni szakmai pályafutása egyből olyan munkával és beosztással kezdődött, ami szélesebb betekintést nyújtott az egészségügy teljes spektrumába. Az 1876. évi XIV. törvény végrehajtása kapcsán Kenézy számára nyilvánvalóvá váltak a legégetőbb feladatok. Debrecen lakossága ebben az időben többszörösére növekedett és egyre több városkörnyéki mezőgazdasági területet kellett bevonni a városi élettérbe. Ennek szükségszerű következménye volt az, hogy a csatornahálózat fejlesztésre szorult. A belvárosba behurcolt és a csapadék révén a csatornákba jutó sár okozta dugulások szintén elengedhetetlenné tették a szilárd burkolatú úthálózat bővítését.

A közegészségügyi törvény 50. \$-a kimondta, hogy „szülésznői gyakorlatra csak az bocsáttatik, ki az ország területén érvényes szülésznői oklevéllel vagy tiszti fốorvosi képesito" okmánnyal van ellátva." A helyhatóság illetékes szakembereként, egy hajdúszoboszlói bába fiaként és Kézmárszki tanítványaként már egyáltalán nem meglepő, hogy a debreceni bábaképző igazgatójának 1896-ban Kenézy Gyula kapott kinevezést. Hasonló okok miatt („154. S A törvényhatóság és közegei [...] (d) nyilvántartja a hatóság területén létezö lelenczeket, siketnémákat, elmekórosokat, bárgyúkat, dajkaságba adottakat és azok tartása és ápolására, valamint a vagyontalan betegek gyógyitására felügyel, illetöleg a helyi viszonyokhoz képest eljár") azon sem lepődhetünk meg, hogy Kenézy Gyula 1903-ban a debreceni gyermekmenhely igazgatói feladatainak ellátására nyert kinevezést. 
A képviselőház Közoktatási Bizottsága már 1883-ban elhatározta, hogy az akkori meglévő két egyetem (Budapest, Kolozsvár) mellett egy harmadik és egy negyedik egyetemet létesít. Debrecenben 1908-ban Állandó Egyetemi Bizottságot hoztak létre Kenézy Gyula elnökletével. A város felajánlott 112 hold földet a Nagyerdő területéből, továbbá a Bábaképezde és a Kórház épületeit, klinikai osztályonként 5000 aranykoronát, továbbá 12 intézet, egy központi épület és a kazánház felépítését. Ezek ismeretében jogosnak tartjuk Kenézy indulatos levelét a minisztériumhoz: „Az egyezség szerint Debrecen nem megkapta, hanem megvette az egyetemet."1912-ben törvénytervezet született arról, hogy a harmadik egyetemet Debrecenben építik meg, de orvosi fakultás nélkül. Kenézy kitartó közbenjárásával meggyőzte Debrecen akkori vezetőit az orvosi fakultás szükségességéről. A minisztérium és az országgyủlés látva Debrecen város páratlan áldozatkészségét és a vezetők kitartó utánajárását, 1912. július 7-én végleges törvénytervezetet fogadott el az egyetem létesítéséről. A tervezet egy bekezdése csalódást okozott, miszerint az orvoskar "fokozatos fejlesztés elve alapján” állítandó fel. A törvény Ferenc József császár aláirásával 1912. július 11-én jelent meg (1912. évi XXXVI. törvénycikk).

\section{Nendtvich Andor, királyi tanácsos}

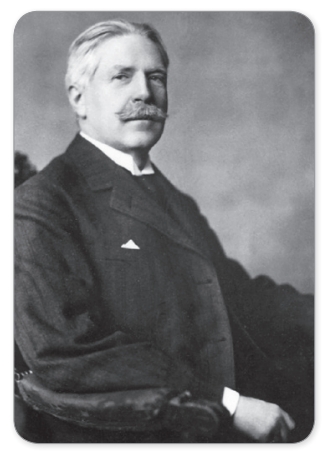

Nendtvich Andor (Pécs, 1867. október 2.-Pécs, 1951. május 6.) királyi tanácsos, a Magyar Városok Országos Kongresszusának alelnöke, a Stefánia Országos Anyavédő és Csecsemővédő Egyesület pécsi fiókjának elnöke, a pécsi evangélikus egyházgyülekezet felügyelője, Pécs szabad királyi város polgármestere volt a XX. század elején. A város önálló érdekének biztosítását fö hivatásának tekintette, ennek érdekében figyelme 1907-ben a legnagyobb kultúrintézmény, az egyetem felé fordult. 1907. január 23-án a közgyűlés Pécs város nevében feliratot intézett a képviselőházhoz, valamint felterjesztést küldött a vallás- és közoktatásügyi miniszterhez. A Dunántúl törvényhatóságainak és vezető társadalmi személyiségeinek részvételével nagybizottságot alapított az egyetem propagálására. (1910. október 17., 18. és 1911. április 24., 26.).

1908-ban köztudomásra jutott, hogy gr. Apponyi Albert vallás- és közoktatásügyi miniszter nagyszabású egyetem-alkotási tervet kíván hozni. 1912-ben Pécs nem került be az egyetemalapító városok sorába, csak Pozsony és Debrecen kapott lehetőséget. Végül az első világháború miatt kialakult politikai helyzet következtében a Pozsonyból menekülni kényszerülő Erzsébet Tudományegyetem Pécsre való áthelyezésének ügyében minden követ megmozgatott. A döntéskor (1921-ben) Pécs városa még szerb megszállás alatt volt, Nendtvich Andor pedig Sásdról tartotta a kormány és a pécsi ellenállási mozgalom vezetőivel a kapcsolatot. A csaknem két évtizedes polgármestersége idején a város olyan anyagi és kulturális előnyt szerzett, amely az universitas elhelyezésénél is nagy súllyal esett latba. 


\section{Adatok közéleti szerepvállalásáról}

Kenézy Gyuláról az 1901-es Tiszti címtárban a követkeő adatokat találjuk:

- Debreczeni orvos-gyógyszerész egylet, elnök

- Debreczeni Bábaképző Intézet, igazgató

- Debreczeni Kereskedelmi Akadémia, tanár

Ebből a listában felismerhetjük budapesti barátainak tevékenységét is. Sógora, Bársony János évekkel korábban alakította meg a Magyar Nemzeti Orvosegyletet és édesanyja, valamint további barátai is, nem beszélve a közelmúltban megalkotott közegészségügyi törvény előírásairól, kellő útmutatást adtak számára a bábaképzés teendőiről.

A Belügyi közlöny 1903-ban az alábbiakat közölte:

„Állami gyermekmenhelyi kinevezések [...] A belügyminiszter a debreczeni állami gyermekmenhely igazgató föorvosi teendöinek ellátásával dr.Kenézy Gyulát, a debreczeni m.kir. bábaképezde igazgatóját bizta meg."

Önkormányzati funkciójából és a közegészségügyi törvény előírásaiból adódóan szintén magától értetődőnek tekinthetjük, hogy a gyermekmenhely vezetésére is Kenézy Gyula kapott megbízást. Ez a kinevezés időben egybe esett egy különösen fontos eseménnyel, de erről részleteiben csak később számolok be.

Kenézy Gyuláról a Tiszti címtár 1907-es évfolyama így emlékezett meg:

- Debreczeni orvos-gyógyszerész egylet, elnök

- Debreczeni Bábaképző Intézet, igazgató

- Magyar Kir. Áll. Gyermekmenhely, Debreczen, igazgató főorvos.

Kenézyhez kötheto” adatokat találhatunk a „Debrecen város történeti kronológiája VII. 1901-1911" címü kötetben is:

- 1909. január 8. Megalakult Debrecenben a munkásgimnázium bizottsága Kenézy Gyula irányításával. A tanítás három tanfolyam keretében indul.

- 1909. február 9. Megalakult Debrecenben a szanatórium Egyesület. Elnöknek Kovács József polgármestert, ügykezelő elnöknek Kenézy Gyulát választották.

- 1911. február 3. Debrecen város törvényhatósági bizottsága a Nagyerdő 574 kh területét parkerdőnek nyilvánította. Az erdő többi részét-1782 kh-kitermelésre jelölte ki előzetes betelepítés után.

- 1911. február 4. Dr. Kovács Gábor egyetemi tanár előadást tartott a Munkásotthonban „A brüsszeli fogyasztási szövetkezet fejlődése” címmel.

- 1911. május 14: A létesítendő egyetem ügyében kereste fel Debrecent Balogh István államtitkár, dr. Tóth Lajos miniszteri tanácsos, Mandelló Gyula osztálytanácsos és Korb Flóris építész.

- 1911. május 19. Debrecen város közgyülése határozatot hozott telekszervező és -értékesítő rt. létesítésére 1,5 milliós alaptőkével.

- 1911. július 7. Kenézy Gyula föorvos kezdeményezte egy munkásotthon létrehozását. 
- 1911. október 15. A Debreceni Hitelbank 100000 koronát szavazott meg a létesítendő debreceni egyetem javára.

- 1911. október 26. Több mint 500 ember utazott fel Budapestre, hogy nyomatékkal kérje az országgyűléstől, a kormánytól: létesüljön Debrecenben egyetem.

A városi történeti kronológia szemelvényei megerősítik, hogy Kenézy rendkívül alapos lobbi-tevékenységet folytatott az egyetemalapítás érdekében. Munkájában nagy segítségére volt veje, dr. Kovács Gábor is. Figyelme még a későbbi építkezés munkásainak elhelyezésére, valamint a krónikus betegek rehabilitációjának megteremtésére is kiterjedt.

Az 1911-es Tiszti címtárban Kenézy Gyula a korábbiaknál jóval több adattal szerpel:

- Debreczeni orvos-gyógyszerész egylet, elnök

- Debreczeni Bábaképző Intézet, igazgató, kir. tanácsos

- Magyar Kir. Áll. Gyermekmenhely, Debreczen, igazgató főorvos

- Alföldi hordógyár Rt, elnök

- Első Debreczeni Gőzcukorkagyár Rt, elnök

- Erzsébet Malom Rt, elnök

- Reichmann Ármin-féle Kőbánya Rt, elnök

Az 1911-ben fennálló tisztségei alapján korunk embere rácsodálkozva tapasztalja, hogy az egészségügy, a felsőoktatás és az ipar kapcsolata milyen fontossággal bírt már egy évszázaddal ez előtt is. A szűkebb szakterület mentorálásában már akkor is hasznosnak bizonyult a királyi tanácsosi megbízatás és az ipar döntéshozó testületeinek munkájában való részvétel. Még el sem kezdődött az áhított építkezés, de Kenézy Gyula már 1911-ben előrelátóan érezte, hogy a beruházásokban az uralkodói és parlamenti döntéseken túl az ipar helyi résztvevőire is feladat hárul. Mindez nem volt újdonság Kenézy számára, hiszen budapesti évei alatt jóformán mást sem látott, csak építkezést, építkezést és építkezést, melynek eredményeként az „Üllői úti tengely” egész városrésze nőtt ki a semmiből. Hogy ebben milyen részük volt Korányiéknak, a Bókayaknak, a kormányzati tagoknak és a szabadkőműveseknek, azt egyszerüen megtapasztalta Kenézy Gyula.

A funkciók azonban még tovább sokasodtak az 1914-es Tiszti címtár szerint:

- Debreczeni orvos-gyógyszerész egylet, elnök

- Debreczeni Bábaképző Intézet, igazgató

- Magyar kir. áll. Gyermekmenhely, Debreczen, igazgató főorvos

- Alföldi hordógyár Rt, elnök

- Első Debreczeni Gőzcukorkagyár Rt, elnök

- Erzsébet Malom Rt, elnök

- Reichmann Ármin-féle Kőbánya Rt, elnök

- Magyar Tarmac Rt, elnök

- Fiatalkorúak felügyelőhatóságai, debreczeni ítélőtábla, elnökhelyettes 
- Délmagyarországi Magyar Közművelődési Egyesület debreczeni osztály, alelnök

- Julián-Egyesület debreczeni bizottsága, elnökségi tag (udv. tanácsos) Délmagyarország Horvát-Szlavóniai magyar szórványtelepülések lakosainak társadalmi és művelődési gondozása, gazdasági támogatása

- Debreczen szab. kir. város zeneiskolája, elnökségi tag

Érzékelhető e felsorolásból, hogy a szilárd útburkolat bővítése Debrecenben nem csak az egyetem építésével függ össze, hanem a város közegészségügyével is. A lakosság rohamos növekedésével és a város lakott övezetének bővülésével egyre égetőbbé vált a csatorna-rendszer bővítése. A szabad királyi város önkormányzatában talán éppen Kenézy volt az, aki legkönnyebben átlátta ennek a közegészségügyi szerepét abban a korban, amikor még kolera- és tífuszjárványok tizedelték az ország lakosságát. Emberi léptékben egyáltalán nem rég volt az 1879-es szegedi árvíz, ami 150 ember és 2500 lakóház pusztulását eredményezte. Árvíztől ugyan Debrecenben nem kellett tartani, de a bővülő csatornahálózat a csapadék által lemosott sártól rendszeresen felmondta a szolgálatot és járványügyi szempontból tarthatatlan helyzetet teremtett. Logikus következtetése volt az elöljáróknak, hogy csak a szilárd burkolatú úthálózat kiépítésével, bővítésével orvosolható ez a probléma.

Az ítélőtáblai előmenetel szintén nem meglepő annak fényében, hogy a néhai professzor veje a Debreceni Egyetem kinevezett jogász professzora volt, maga a professzor pedig a gyermekmenhely igazgatója és a gyámügyek önkormányzati felügyelője is volt egy személyben.

A Honvédségi Közlöny (1915) szerint Ö császári és apostoli királyi Felsége július 27-én Bécsben kelt rendeletével a m. kir. Orvosi tisztikarban a háború tartamára kinevezte Kenézyt 2. osztályú fötörzsorvossá.

E szemelvény kapcsán emlékeztetem az olvasót, hogy Kenézy híres tanárai az 1848/49-es események kapcsán milyen érdemeket szereztek azzal, hogy az általuk vezetett gyógyító intézményeket hadi kórházzá alakították. 1915-ben már tombolt az első világháború és a keleti országrész már az orosz csapatok megszállása alatt állt.

A következő szemelvény hivatott utalni arra, hogy az adott helyzetben még a világháború ténye is segített a Debreceni Egyetem orvosi fakultásának és a klinikatelepnek a létre hozásában.

Interpelláció az országgyülésben 1916. január 19-én:

[...] A gyakorlatban tapasztalható, hogy a betegségek leginkább háborúban szaporodnak, különösen a mozgósítás és a békekötés idején. [...] Tekintve, hogy győzelmes hadseregünk mindenütt a győzelem még további reményével halad előre, talán nincs messze az idő, amikor a béke kérdése minket is közvetlen közelről érint. [...] Láttam, hogy vannak nagyvárosok, mint, pl. Debreczen, az ottani orvos urak minden segítségével nem voltam képes elérni azt, hogy helyben állíttassék fel egy osztálya valamely kórháznak, ahol e szerencsétlen katonák harcztérről hazaérkezve ott azonnal a szükséges orvosi kezelés alá vétessenek. 
Kenézy Gyula a Tiszti címtár 1916-os évfolyamában:

- Debreczeni orvos-gyógyszerész egylet, elnök

- Debreczeni Bábaképző Intézet, igazgató

- Magyar kir.áll. Gyermekmenhely, Debreczen, igazgató föorvos

- Alföldi hordógyár Rt, elnök

- Első Debreczeni Gőzcukorkagyár Rt, elnök

- Erzsébet malom Rt, elnök

- Reichmann Ármin-féle Köbánya Rt, elnök

- Magyar Tarmac Rt, elnök

- Fiatalkorúak felügyelőhatóságai, debreczeni ítélőtábla, elnökhelyettes

- Délmagyarországi Magyar Közművelődési Egyesület debreczeni osztály, ügyvezető elnök

- Julián-Egyesület debreczeni bizottsága, elnökségi tag (udv. tanácsos) Délmagyarország Horvát-Szlavóniai magyar szórványtelepülések lakosainak társadalmi és művelődési gondozása, gazdasági támogatása

- Debreczen szab. kir. város zeneiskolája, elnökségi tag

Új elemként jelentik meg a tisztségek között a Julián Egyesület elnökségi tagsága. A Julián Egyesület nevét Juliánusz barátról kapta és célkitűzése a szerzetesbarát szellemiségét ápolva a szórványban élő magyarság felkutatását és támogatását tűzte ki célul. Féleértés ne essék, Kenézy Gyula idejében a nagy Magyarország horvát-szlavóniai területein nem a magyar nyelv volt a hivatalos nyelv és a magyar kultúra sem tartozott a közfinanszírozás prioritásai közé még a dualizmus korában sem. Ezeknek a területeknek a többnyire parlamenti képviselői sem magyar anyanyelvű nemesek voltak. Ilyen körülmények közepette a Julián-Egyesület és a szabadkőműves páholyok voltak azok a szervezetek, amelyek anyagi és szellemi támogatásuk révén életben tartották a magyar kultúrát. Sok esetben szó szerint egyes magyarlakta települések túlélését biztosították. Jó példa volt erre egy az első világháborúban elpusztított falu, melyet a szabadkőműves támogatással megvalósított újjáépítés emlékére Kőművesfalvának neveztek el.

Mint láttuk, Kenézy szabadkőműves tevékenysége budapesti indíttatással kezdődött, s ebben minden bizonnyal nagy szerepe volt a Bókayaknak is. Debrecenbe viszszatérve Kenézy Gyula hamarosan tagja, majd nagymestere (vezetője) lett a Haladás páholynak. 1913-ban több társával kilépett a Haladás páholyból és megalapította a Kőrösi Csoma páholyt, melynek programját nem más, mint veje, dr. Kovács Gábor írta meg. Budapesti mentora, Bókay Árpád, a magyarországi szimbolikus nagypáholyt alakította hadikórházzá a világháború kezdetén. Nem csoda, hogy ugyanezt Kenézy nem tudta megtenni Debrecenben, de az egykori debreceni kóroda épületének hadikórházzá alakítása és a klinikatelepi építkezések erőltetése ugyanezt a célt szolgálták.

Az 1918-as Tiszti címtárban a több ismétlődés mellett ismét felismerhetők új elemek: 
- Debreczeni orvos-gyógyszerész egylet, elnök

- Debreczeni Bábaképző Intézet, igazgató

- Magyar királl. Gyermekmenhely, Debreczen, igazgató föorvos

- Debreczeni Hitelbank, alelnök (udv.tanácsos)

- Első debreczeni gőzcukorkagyár Rt, elnök

- Erzsébet malom Rt, elnök

- Reichmann Ármin-féle kőbánya Rt, elnök

- Magyar Tarmac Rt, elnök

- Fiatalkorúak felügyelőhatóságai, debreczeni ítélőtábla, elnökhelyettes

- Délmagyarországi Magyar Közművelődési Egyesület debreczeni osztály, ügyvezető elnök

- M. kir. Tudományegyetem (1914), Debreczen, szül-nőgyógy. ny. r. tanár

Minden képzeletet felülmúl az, hogy a filantróp Kenézy pénzügyi körökben is befolyást nyert és korábbi megbízatásai közművelődési területen is szélesedtek.

A Hivatalos Közlöny egyik 1919-es számában olvashatjuk:

Megerősítések: [...] A magyar vallás- és közoktatásügyi miniszter a debreczeni tudományegyetem újonnan megalakult orvostudományi karának ama határozatát, mellyel a kar dékánjává dr. Kenézy Gyulát, prodékánjává pedig dr. Orsós Ferenc ny. r. tanárokat választotta meg, jóváhagyólag tudomásul vette, a folyó 1918/19. tanév hátralevő tartamára megerősítette (1918. december 11.)

Jelentős részében elkészült a „nagy mü”, vagy legalább is visszafordíthatatlanná vált annak elkészülte, hiszen a királyi pár avatta fel az orvosi kar föépületét. Egy évszázad távlatában is úgy tűnik, hogy Kenézy dékáni kinevezése elkerülhetetlen volt.

Majd még ugyanebben az évben a Hivatalos Közlönyben újra feltűnik Kenézy neve:

Megerősítések: [...] A vallás- és közoktatásügyi miniszter a debreczeni magyar tudományegyetemen az 1919/20 tanévre dr. Kenézy Gyulának a tudományegyetem rektorává történt megválasztását jóváhagyólag tudomásul vette és ezen tisztségében (1919. szeptember 17.) megerősítette.

Budapesten a háború szinte kiszippantotta a hallgatókat, a leszerelés után viszont dömping mutatkozott. Az utolsó békeévhez viszonyítva több mint kétszer annyi medikus (6.526 fó) kívánta folytatni félbehagyott tanulmányait. A túl nagyra duzzadt hallgatói létszámok és a forradalmak tapasztalata mellett ez is egyik előidézője volt az 1920. évi XXV. törvény, közkeletűbben a „numerus clausus” megszületésének, melynek kezdeményezése épp a budapesti orvoskarról indult ki, és egyik legfőbb hangadója, sajnos, éppen Bársony János volt. 
A dékáni tapasztalatok birtokában és a még folyamatban lévő grandiózus beruházás egyik fö motorjaként, a szabad királyi város Egyetemi Bizottságának elnökeként nem lepődhetünk meg azon, hogy az elsőként megválasztott Bernolák Nándort a következő ciklusban Kenézy Gyula követte a rektori székben.

Csaknem egy évtized múltával a Kenézy Gyuláról ezt találjuk a Tiszti címtárban (1927):

- Szülészeti Klinika, Debreczeni Bábaképző Intézet, igazgató

- Magyar kir. áll. Gyermekmenhely, Debreczen, igazgató főorvos

- Debreczeni Hitelbank, alelnök (udv. tanácsos)

- Első debreczeni gőzcukorkagyár Rt, elnök

- Erzsébet malom Rt, elnök

- Reichmann Ármin-féle kőbánya Rt, elnök

- Magyar Tarmac Rt, elnök

- Fiatalkorúak felügyelőhatóságai, debreczeni ítélőtábla, elnökhelyettes

- Délmagyarországi Magyar Közművelődési Egyesület debreczeni osztály, ügyvezetö elnök

- M. kir. Tudományegyetem (1914), Debreczen, szül-nőgyógy. ny. r. tanár

Ebben a felsorolásban már új szerepek nem találhatóak, Kenézy mindent elért, amit nagy ívű elképzeléseiben meg akart valósítani. A klinikatelep utolsóként emelt épülete, a Kenézy-villa is elkészült, 1926-ban beköltözött a család. A történet szomorú folytatásáról elődeim több írásban beszámoltak, ezért célkitűzéseimhez híven én igyekszem Kenézy személyes kapcsolataira koncentrálni és a személyiségét formáló körülményeket, kapcsolatokat fürkészni.

\section{Egy országgyưlési képviselő szerepe}

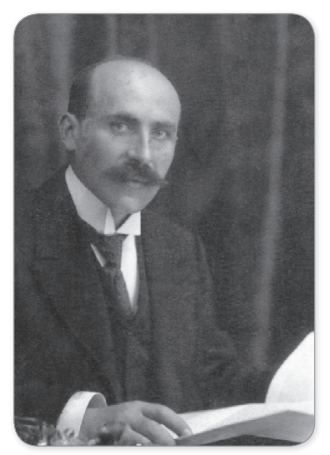

Bernolák Nándor (Radvány, 1880. október 2.-Budapest, 1951. augusztus 8.) magyar jogász, politikus, miniszter, egyetemi tanár. Jogi tanulmányait Budapesten, Berlinben és Kolozsvárott folytatta, de látogatta a nápolyi, torinói, római és párizsi egyetemeket is. 1908-ban tanárrá nevezték ki a kassai jogakadémián, 1913-tól pedig ítélőtáblai bíró volt Kassán. 1914-ben a debreceni egyetemen a büntetőjog tanára lett. Létre hozta az egyetemi diákasztalt (Mensa Academica), az Országos Bírói és Ügyészi Egyesületet, a Szent László kollégiumot, az Egyetemi Kórházak egyesületét, valamint az ifjúság önképzését és segélyezését szolgáló Egyetemi Kört. Az első debreceni rektorválasztásnál (1915) egyhangúlag őt választották meg. 1917-ben a jogi kar dékánja lett. A kommunista korszakban (1919 április- 
június) fogságban volt. Az 1920-22-i nemzetgyűlésen Debrecen képviselőjeként (Debreczen III. választókerület) keresztény nemzeti programmal választották meg. Ő töltötte be az első Bethlen-kormányban a népjóléti- és munkaügyi miniszter tisztségét 1921. április 14. és 1922. június 16. között. 1922-től ügyvédként praktizált és egyetemi magántanár volt.

\section{A miniszterelnök szerepe}

Tisza István édesapja borosjenői Tisza Kálmán politikus, korábban miniszterelnök $(1876,1883)$ és miniszter volt. Édesanyja Degenfeld-Schomburg Ilona grófnő, eredetét tekintve BadenWürttembergből származó német grófi család magyarországi ága. 1903. november 3-án a király miniszterelnökké nevezte ki és a belügyi, valamint a személye körüli minisztérium vezetésével bízta meg. A parlamentben ellehetetlenült állapotok és a közvélemény példátlan polarizálódása miatt 1905. január 3-án a király feloszlatta az országgyülést és új választásokat írt ki. A választási vereséget követően Tisza 1906 és 1910 között csak a

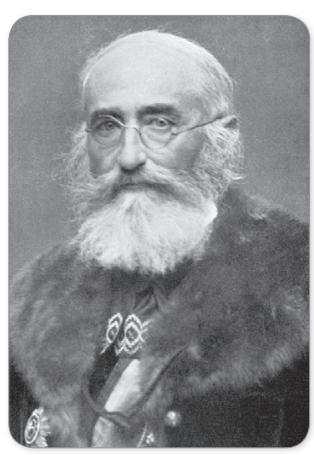
förendi ház működésében vett részt. A Függetlenségi Párt vezette kormánynak azonban egyetlen, a Monarchián belül a magyar befolyást erősíteni kívánó törekvését sem sikerült megvalósítania, s 1909. április 25-én a koalíciós kormány végül lemondott. 1910. február 19-én Tisza megalapította a Nemzeti Munkapártot, amely győzött is az az évi júniusi választásokon. Kormányalakítást azonban nem akart vállalni, részben a Ferenc Ferdinánd trónörökössel fennálló kibékíthetetlen ellentéte miatt.

1912. május 22-én Tisza Istvánt választották a képviselőház elnökévé; erre 1912. május 23-án, a vérvörös csütörtökön a szocialisták által szervezett tüntetés volt a válasz. 1913. június 7-én az uralkodó ismét őt bízta meg kormányalakítással. Második kormányfői periódusában Tisza a bizonytalannak ítélt nemzetközi helyzetben az államhatalom megszilárdítását tartotta legsürgetőbb feladatának. Mivel ellenezte a Ferenc József halála után 1916. december 30-án trónra lépett IV. Károly király mérsékelt reformokkal kísérletező politikáját, 1917. május 23-án az uralkodó felszólítására benyújtotta lemondását. A mögötte álló parlamenti többséggel azonban továbbra is meg tudta akadályozni a választójogi reformot. 1917. június 15. után maga is a frontra ment, mint a debreceni huszárezred parancsnoka.

Tisza István szerepe a Debreceni Tudományegyetem létrejöttében közismert.

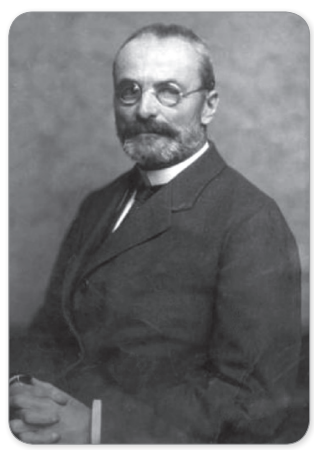




\section{Ki volt Kenézy Gyula?}

Személyiségjegyeit véleményem szerint az alábbiak szerint foglalhatjuk össze röviden:

- A dualizmus korában élt humanista;

- a polgárosodás és a második ipari forradalom lelkes híve;

- a Debreceni Tudományegyetem és az Orvoskar létrehozásának fö szervezője;

- a hatékony társadalmi és gazdasági kapcsolatokra alapozott egészségügy- és oktatásfejlesztés debreceni mentora;

- a szülészeti klinika első igazgatója.

\section{Kenézy utóélete}

Kenézy Gyula 1931. november 25-én meghalt gégerákban. Felesége korábban öngyilkos lett. Lányuk Lujza, a tehetséges közgazdász-jogász professzor Kovács Gábor felesége volt. Házasságuk nem volt sikeres. Kovács Gábor már 1914-ben Marosvásárhelyre, majd Budapestre került. Sajnos, ő is az 1919/20-as spanyolnátha sokmillió áldozatának egyike lett. Gyermekkorát és lánykorát kivéve Kenézy Lujza élete nem volt boldogsággal teli. Tönkrement házassága, özveggyé válása, édesanyja tragikus halála, majd édesapja elvesztése elviselhetetlenné tette bánatát és önkezével vetett véget életének 1932-ben.

Debreceni tisztelői mind a mai napig úgy tudták, hogy lányának halálával Kenézy Gyula családfája véget ért. Egy mesébe illő történetként Balogh Gábor, a Kecskeméti Egyetem tanára 2017-ben jelentette meg „Az Óperencián innen és túl” című családfakutatását, melyben tárgyi dokumentumokkal, családi emlékekkel, fényképekkel mutatja be felmenőit - köztük Kenézy Gyula professzort - s egyúttal a populáció-genetika legmodernebb módszereivel vezeti vissza őseit évszázadokra.

\section{Telegdi Mária}

Nem kis meglepetést okozva számomra, Balogh Gábor írja, hogy „Telegdi Mária dédanyám 1879. január 3-án született Hosszúpályiban, és 1907. április 5.-én halt meg ugyanott. Szülei Telegdi József és Pásztor Rozália. Mivel apja református volt, anyja pedig római katolikus, a fuík apjuk, a lányok anyjuk vallását követték, igy Telegdi Mária dédanyám is római katolikus volt. Apja családja Hosszúpályiból és Biharnagybajomból származott, anyja családja pedig Zala megyéböl jött. Apja kovács volt, de az ö családja eredetileg földmüveléssel foglalkozott, mióta az elsök letelepedtek Biharnagybajomban, késöbb Hosszúpályiban. A debreceni bábaképzö intézetben tanult, 1903-tól szülésznöként dolgozott. Vilma nagymamám 1903 novemberében született Péterfia utca 46. szám alatt, Debrecenben. Itt 
bérelt egy gyönyörü lakást Kenézy Gyula professzor, dédapám, aki Telegdi Mária haláláig gondoskodott róla. Kenézy Gyula dédapámmal 1903 elött ismerkedhettek meg, amikor ö a debreceni bábaképzö intézet igazgatója volt. 1907. április 5.-én, 28 évesen halt meg tbc-ben."

„Mama, akit mindannyian Mamának, vagy Baloghmaminak hivtunk, valójában Vilma volt. Telegdi Vilma 1903-ban született Debrecenben, és 1982-ben halt meg Budapesten. Házasságon kivül született. Anyja Telegdi Mária bábasszony volt, ma azt mondanánk szülésznö, mig apja Kenézy Gyula szülész orvos, a debreceni

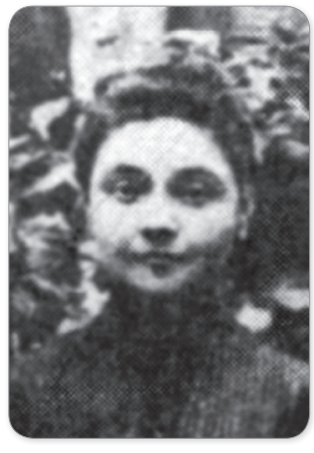
bábaképzö intézet igazgatója, a debreceni egyetem rektora. A professzor Telegdi Máriáról haláláig gondoskodott, de közös lányukat, a nagymamámat, nem vette a nevére. Mária dédanyámmal 1903 elött ismerkedhettek meg, amikor is a debreceni bábaképzö intézet igazgatója volt."

Kenézy unokája, Balogh Sándor így ír nagyapjáról. „Anyám törvénytelen lánya volt egy bábanövendéknek, aki az akkor létrejött Debreceni Orvosegyetemen tanult és boldogult öcsém családfa-kutatásai szerint az egyetem professzorától fogant. Anyám nekünk, gyerekeknek erröl (és sok másról) soha nem beszélt, de öcsém fejébe vette, hogy felderiti ezt a vonalat. Debreceni utazásai után biztos volt abban, hogy Kenézy professzor leszármazottai vagyunk. Magam a családfakutatásnak sok gyakorlati értelmét nem láttam, nem így a fiam, aki ezt a leszármazást be is bizonyitotta. Balogh Sándor Hivö ember volt, emlékszem, sokat villamosoztunk, ilyenkor, ha templom mellett haladunk el, mindig keresztet vetett. Szüleim ateista "vallásuak"voltak, tehát nekem ez mindig furcsa volt. Annyira komolyan vette a római katolikus hitet, hogy születésem után-szüleim tudta nélkül-el is vitt engem megkeresztelni. A kereszteletleneket - enyhe rosszallással - pogányoknak nevezte."

Kenézy Gyula és Telegdi Mária árván maradt leányáról, Telegdi Vilmáról a következőket írja Balogh Gábor: „Tizenhét éves voltam, amikor Mama meghalt, de rengeteg emléket örzök töle. Furcsa módon mindig úgy éreztem, hogy igazán nem ment el soha, itt van velem. Persze gyerekként más dolgok voltak fontosan nekem, mint ma - most nagyon sajnálom, hogy nem kérdezgettem öt többet az életéröl. Szinte mindent, amit róla tudok, szüleim elbeszéléseiböl tudom. Ö akkor „csak” nagymama volt, aki folyton finomságokkal halmozott el. Sokat voltam nála, és mindig éhes voltam. Elöször olajos kenyeret adott,

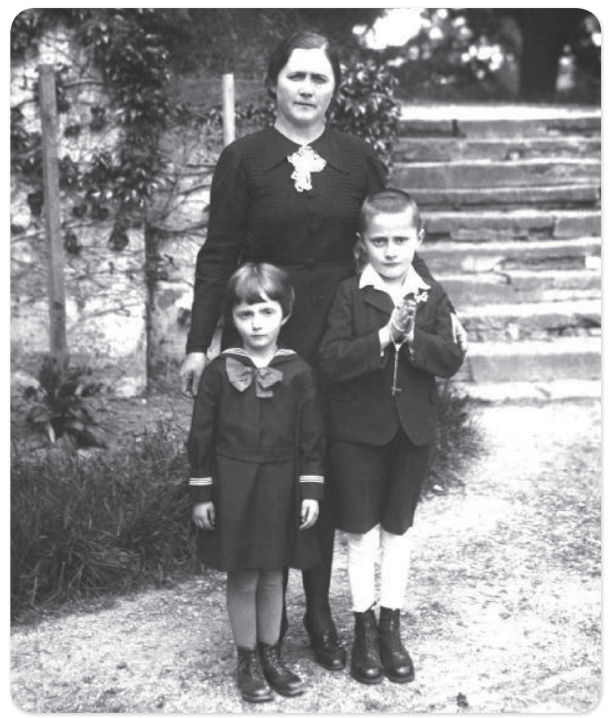




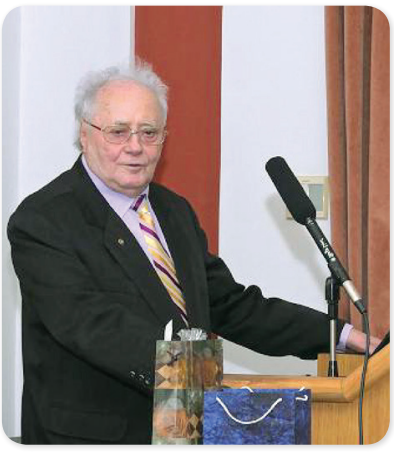

hogy elverjem elsö éhségemet, aztán jött a mákos nudli, a krumplis pogácsa - mai szemmel elképesztöen egészségtelen ételek. Számtalan régi képe volt a családról, nagyapámról, kitüntetések a háborúból - amik mára valószinüleg már örökre elvesztek, a családban már senki nem tud róluk. Ezt rettenetesen sajnálom. A remek krumplis pogácsákat sokszor el is hozta hozzánk nagy ételhordó bádogdobozban, már a Mogyoródi útra is - mígnem már sok lett a három emelet megmászása. "De közel laktok az Úristenhez" - mondogatta pihegve, de a helyzettel megbékélten. Úgy fogadta az öregséget, mint az élet többi nehézségét, végtére is kilenc gyereket szült, de csak apám és Gyuri érte meg a felnöttkor. Az idö elment mellette: konzervnyitót még nem használt, a mozgólépcsöre félt rálépni. Mama "régi itárgyaiból egy festett falitányért és egy konyharuhát öriztem meg."

A legkorábbi fennmaradt kép Telegdi Vilmáról Kenézy Gyula házasságon kívül született lányát mutatja gyermekeivel 1937-ben. Férje, Balogh Sándor fiatalon, 39 éves korában halt meg. Fia Balogh László 1988-ban lett a Szegedi Tudományegyetem tanára.

Balogh Lászlót 2017-ben tudományos konferencia keretében köszöntötték 85-ik születésnapján.

És végül, akinek a nagy előd utóéletét köszönhetjük, Kenézy Gyula dédunokája, az „Az Operencián innen és túl” című családfakutatás szerzője, Balogh Gábor szavaival zárom soraimat:

„Azt hiszem, hogy az egyik legfontosabb kérdés az egyén számára az, hogy ki ö, honnan jött. Nehéz megtalálni helyünket a világban, ha nem tudjuk, kik vagyunk, nem tudjuk, hova haladunk, ha nem tudjuk, honnan jöttünk. Ismerjük szüleinket, jó esetben nagyszüleinket. Két generációra még vissza tudunk emlékezni, de minden eltávozó generációval értékes, pótolhatatlan dolgok merülnek örök feledésbe, ha nem irjuk le, nem adjuk át a következö generációknak. Gyerekeink semmit sem fognak tudni a mi nagyszüleinkröl, unokáink pedig úgyszintén semmire sem fognak emlékezni a mi szüleinkröl. Rajtunk múlik, hogy Léthé vagy Mnémoszüné vizéböl iszunk."

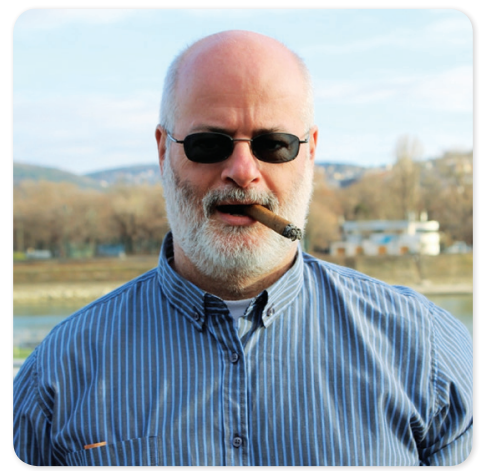




\section{Források}

1876. évi XIV. törvénycikk-a közegészségügy rendezéséről, https://net.jogtar.hu/ getpdf?docid $=87600014$. TV\&targetdate $=\&$ printTitle $=1876 .+\% \mathrm{C} 3 \%$ A9vi + XIV.+ törvénycikk\&referer $=1000$ ev (Letöltés: 2018 . október 15.)

A Semmelweis Egyetem története, http://semmelweis.hu/az-egyetemrol/az-egyetemtortenete/ (Letöltés: 2018. október 15.)

Balassa János (1814-1868), http://baratikor.semmelweis.hu/galeria/page.php?id=81 (Letöltés: 2018. október 15.)

Bársony János (1860-1926) szülész és nőgyógyász. In Magyar Életrajzi Lexikon, http:// mek.oszk.hu/00300/00355/html/ABC00523/01115.htm (Letöltés: 2018. október 15.)

Belügyi Közlöny 1903, https://adtplus.arcanum.hu/hu/view/BelugyiKozlony_1903/?p $\mathrm{g}=0 \&$ layout=s (Letöltés: 2018. október 15.)

Bernolák Nándor (1880-1951), jogász, miniszter, egyetemi tanár, https://hu.wikipedia. org/wiki/Bernolák_Nándor (Letöltés: 2018. október 15.)

Bókay Árpád (1856-1919) belgyógyász, farmakológus, https://hu.wikipedia.org/wiki/ Bókay_Árpád (Letöltés: 2018. október 15.)

Hivatalos Közlöny 1893-1944, https:/dtt.ogyk.hu/hu/gyujtemenyismertetok/jogforrasok/ agazati-kozlonyok/item/287-hivatalos-kozlony (Letöltés: 2018. október 15.)

Honvédségi Közlöny 1874-1948, https://adtplus.arcanum.hu/hu/collection/Honvedsegi Kozlony/ (Letöltés: 2018. október 15.)

Högyes Endre (1847-196) orvos, https://hu.wikipedia.org/wiki/Hőgyes_Endre (Letöltés: 2018. október 15.)

Korányi Frigyes (1827-1913) orvos, https://hu.wikipedia.org/wiki/Kor\%C3\%A1nyi_ Frigyes_(orvos) (Letöltés: 2018. október 15.)

Magyar Közegészségügyi Kronológia 1867-1896, Magyar Tudománytörténeti Intézet Tudományos Közleményei 93. http://real.mtak.hu/55785/1/kozeu_kronologia_ 1867_1896.pdf (Letöltés: 2018. október 15.)

Magyarország tiszti cím-és névtára (1873-1944), https://adtplus.arcanum.hu/hu/ collection/TisztiCimtar/ (Letöltés: 2018. október 15.)

Makara Lajos (1862-1915) orvos, sebész. In Magyar Életrajzi Lexikon, https://www. arcanum.hulen/online-kiadvanyok/Lexikonok-magyar-eletrajzi-lexikon-7428D/m76AF9/makara-lajos-76B9A/ (Letöltés: 2018. október 15.)

Országgyülési Dokumentumok 1861-1990 (Naplók, irományok), https://library. hungaricana.hu/hu/collection/orszaggyulesi_dokumentumok/ (Letöltés: 2018. október 15.)

Tóth Lajos (1856-1926) orvos, államtitkár. In Magyar Életrajzi Lexikon, http://mek. oszk.hu/00300/00355/html/ABC15363/15931.htm (Letöltés: 2018. október 15.)

Tisza István (1981-1918), politikus, miniszterelnök, akadémikus, https://hu.wikipedia. org/wiki/Tisza_István (Letöltés: 2018. október 15.) 
Tisza Kálmán (1830-1902), politikus, miniszterelnök, nagybirtokos, akadémikus, https:// hu.wikipedia.org/wiki/Tisza_Kálmán (Letöltés: 2018. október 15.)

Török József (1824-1899) gyógyszerész, https://hu.wikipedia.org/wiki/Török_József_ (gyógyszerész) (Letöltés: 2018. október 15.)

\section{Irodalom}

Balogh Gábor. Simándi Kenézy Gyula (1860-1931), https://www.academia.edu/ 35488194/Simándi_Kenézy_Gyula (Letöltés: 2018. október 15.)

BALOGH Gábor. Az óperencián innen és túl, Kecskemét, 2017. https://www.academia. edu/36058298/Az_óperencián_innen_és_túl (Letöltés: 2018. október 15.)

Károlyi Géza és Szabó Szilárd és P. Szabó Béla. „Kovács Gábor”. In „Ernyedetlen szorgalommal ... ": A Debreceni Tudományegyetem jogász professzorai (1914-1949), szerkesztette P. Szabó Béla, 95-107. Historia Facultatis Iuridicae IV. Debrecen: Debreceni Egyetem Állam- és Jogtudományi Kara, 2014.

KenÉzy Gyula. A szabadkömüvesség lényege, Debrecen, 1910.

Kovács I. Gábor. „Kovács Gábor (1883-1920) miskolci születésű közgazdász professzor életpályája: A református tanárcsaládtól a debreceni tudományegyetemi katedrán át a budapesti Marx-Engels Munkásegyetemig". Történelem és Muzeológia Internetes Folyóirat Miskolcon 2 (2015), 47-56. http://www.hermuz.hu/hom/ images/latogatoinknak/history-journal/pdf/2_2015_2/Kovacs-I-Gabor.pdf (Letöltés: 2018. október 15.)

Lampé László. Dr. Kenézy Gyula (1860-1931), A Debreceni Orvosképzés nagy alakjai 5. Debrecen, 1994.

Lampé László. „Kenézy Gyula, a Debreceni Egyetem első orvos rektora”. Gerundium 5, 1-2 sz. (2014): 5-27.

ÖLveTI Gábor. „Debrecen Szabad Királyi Város Közigazgatási Bizottságának hatásköre és szervezeti felépítése a dualizmus korában”. In Hajdu-Bihar Megyei Levéltár Évkönyve 29., 231-248. Debrecen, 2002,

P. SzABó Béla. „Bernolák Nándor”. In „Ernyedetlen szorgalommal ...”: A Debreceni Tudományegyetem jogász professzorai (1914-1949), szerkesztette P. Szabó Béla, 179-203. Historia Facultatis Iuridicae IV. Debrecen: Debreceni Egyetem Állam- és Jogtudományi Kara, 2014.

Schmeltzer-PokÁnka Éva. „Nendtvich Andor díszdoktori kinevezése a pécsi Erzsébet Tudományegyetemen". Per Aspera Ad Astra 1, 1. sz. (2014): 184-194.

Szállási Árpád. Debrecen elsö orvos akadémikusa Török József (1813-1894), http:// www.orvostortenelem.hu/tankonyvek/tk-05/pdf_Szallasi/torok_jozsef_konyv.pdf (Letöltés: 2018. október 15.)

Szállási Árpád. Dr. Bókay Zoltán (1885-1955), A Debreceni Orvosképzés nagy alakjai 24. Debrecen, 2009. 